\title{
DE LA SANTA DOCTRINA AL ESPÍRITU PÚBLICO \\ (SOBRE LAS FUNCIONES DE LA CRÓNICA EN MÉXICO)
}

¿Por qué el sitio tan marginal de la crónica en nuestra historia literaria? Ni el enorme prestigio de la poesía, ni la seducción omnipresente de la novela, son explicaciones suficientes del desdén casi absoluto por un género tan importante en las relaciones entre literatura y sociedad, entre historia y vida cotidiana, entre lector y formación del gusto literario, entre información y amenidad, entre testimonio y materia prima de la ficción, entre periodismo y proyecto de nación. Muchos de los grandes escritores mexicanos han intentado la crónica que, por ejemplo, ocupa un espacio fundamental en la obra de Guillermo Prieto, Ignacio Manuel Altamirano, Francisco Zarco, Manuel Payno, José Tomás de Cuéllar, Ángel de Campo (Micrós), Manuel Gutiérrez Nájera, Amado Nervo, Artemio de Valle-Arizpe, Alfonso Reyes, Martín Luis Guzmán, Salvador Novo. Y sin embargo, el género aún no recibe la atención que sus logros merecen. Así, pues, en estas notas, centradas en cinco autores, intento aproximarme a las causas de la consideración del público y la desconsideración de los historiadores literarios.

\section{LAS GANANCIAS DEL REINO}

En el siglo XVI, frailes ávidos de conversiones y soldados de mirada latifundista escriben, con pasmo y escándalo moral, crónicas alucinantes. Hoy los más conocidos son los soldados, Bernal Díaz del Castillo y Alvar Núñez Cabeza de Vaca, pero los más asiduos son los frailes, que viajan enumerativamente a través de paisajes que los aturden y costumbres que, agua bendita en mano, ayudan a destruir. No hay preocupación específicamente literaria en esta urgencia de ampliar los territorios del reino de 
este mundo y el reino de los cielos, y con todo, el resultado suele ser notable, la belleza expresiva fluye a través de la prédica, del sentido del detalle, del refrendo de lealtades.

Ni soldados ni frailes se proponen hacer historia o hacer literatura. Para ellos cronicar es asir las sensaciones del instante, capturar a Cronos, defenderse de las versiones de los enemigos, celebrar de modo implícito y explícito su propia grandeza, salvar almas y anunciar la salvación colectiva, compartir las experiencias únicas. Bernal Díaz hace la apología pro vita sua:

mas si bien se quiere notar, después de Dios, a nosotros los verdaderos conquistadores, que lo descubrimos y conquistamos y desde el principio les quitamos sus ídolos y les dimos a entender la santa doctrina, se debe a nos el premio y galardón de todo ello primero que otras personas, aunque sean religiosos, porque cuando el principio es bueno y medio alguno y al cabo todo es digno de loor...

Es reciente la aceptación de la calidad literaria de la crónica de la conquista. Por mucho tiempo fue vista como materia prima de la historia nacional, de la historia de las religiones, del triunfo de la civilización sobre la barbarie (hasta hace muy poco los hispanistas no concedían el rango de "civilización" a la variedad del mundo indígena). Hoy en los relatos, fantásticos o veraces, la atención se ha desplazado al logro verbal.

A los entusiasmos épicos los sucede la convicción más que rentable: la historia se ha detenido, y aquí, ahora, se construye otro reino de Dios. Por más de dos siglos, la ilusión teocrática vuelve secundaria a la crónica, que sólo se rehabilita a fines del siglo XVIII, al amparo de la moda.

\section{DA CUENTA DE LAS ACCIONES DEL PAÍS NUEVO}

En la primera mitad del siglo XIX, la crónica es, en lo fundamental, asunto de los liberales. Obligados a la vocación múltiple, los hombres de la Reforma ven en la crónica (algo que según ellos sin ser exactamente literatura, no deja de serlo) la oportunidad de combinar en un solo texto el alegato político, la memoria histórica, el mensaje a los amigos, y el recordatorio a la sociedad de que la nación existe porque hay quien la describa y aclare sus realidades al nombrarlas.

1 Bernal Díaz del Castillo, Historia verdadera de la conquista de la Nueva España, $4^{\text {a }}$ ed., Porrúa, México, 1955, t. 2, p. 360. 
En el concepto de Historia que los liberales manejan (nutrido de la revolución de Independencia de Estados Unidos y de la Revolución Francesa), el prerrequisito es la sensación de autonomía, cuyas expresiones deben ser concretas, cotidianas. Historia es destino individualizado de los pueblos; Historia es vislumbramiento de la armonía posible de la nación a partir de las libertades que se conquistan; Historia es aquello que, desde el porvenir, juzga y ordena lo que se vive; Historia es en México el flujo de hechos que encauza la idea de progreso, el registro de éxitos y fracasos de un pueblo en el interminable camino de la esclavitud a la justicia social. Por eso, la crónica, al verter literariamente vivencias locales y nacionales, es inmejorable aliada y cómplice de la Historia.

En su oportunidad, los conservadores ven en la crónica la exaltación de las claves de la memoria, el inventario de bienes en peligro, la invocación de las seguridades terrenales, y por estar tan a la defensiva pierden la batalla del género. Los liberales tienen a su favor el ímpetu de la secularización en la capital de la República, que vuelve rápidamente anacrónico el ritmo de vida en el interior y que da el tono y los temas de la crónica en el XIX (en el XX el tótem será la modernización).

Por su condición inicial (dueños de la palabra en un mundo informe, poseedores de la expresión en un medio analfabeto), los escritores mexicanos se constituyen durante más de un siglo en gremio privilegiado que a través de un medio poderoso - la imprenta - y de uno subsidiario - la memorización- difunden consignas y proclamas (en prosa o en verso). No se proponen -conscientemente, como sus contrapartidas europeas-, liberar a la burguesía y erradicar el monopolio feudal a través de la imprenta. Tampoco enfrentan abiertamente la literatura (quehacer individual) con la todopoderosa cultura oral que "preservaba, ritualizaba y adaptaba el patrimonio colectivo" y que en América Latina sólo perderá terreno a principios del siglo $\mathrm{XX}$, más de un siglo después que en Europa, para iniciar su vida subterránea con el primer apogeo de la tecnología y la difusión de la educación universal.

Ambas instancias (la difusión universal y la acumulación del conocimiento que permite el libro impreso) son armas de dos filos (Jean Franco). Conquistada la libertad de imprenta, instrumento de la burguesía, sus productos deberán extenderse y así por ejemplo el proceso de alfabetización y educación en Francia y en Inglaterra a mediados del siglo XIX requiere, para contrarrestar la formación de ideologías subversivas, nuevos instrumentos ideológi- 
cos como la prensa popular. Pero entre la imprenta como instrumento de la burguesía europea y la imprenta en los países periféricos surge la gran diferencia, el abismo entre "civilizados" y "bárbaros" o más bien entre asimilados y marginados.

En México, la imprenta ahonda el abismo entre "civilizados" y "bárbaros", y al mismo tiempo, al ser tan abrumador el analfabetismo, la prensa resulta inmejorable instrumento crítico. De modo simultáneo, transmite, crea, enlaza sentimientos y pensamientos políticos, y afina la idea que nació al unificar el lenguaje, el ya compartido o el que de las élites se transmite gradual y fragmentariamente al resto de la población. Paradoja que no lo es tanto: el grado de libertad de expresión determina, por diversas razones, el grado de represión directa de las clases desposeídas. $\mathrm{Al}$ confinarse en sectores reducidos la libertad de leer, de ilustrarse y de criticar, la literatura acrecienta su importancia.

En las primeras décadas del XIX, las academias literarias (enclaves de hombres cultos que por lo general ya no son sacerdotes) prueban categóricamente la nueva posibilidad: el saber fuera de la Iglesia. Al divulgar las escuelas oficiales otra visión de la historia, concluye la dictadura eclesiástica. En los países latinoamericanos, el hombre de letras sustituye al sacerdote en diversas funciones: la interpretación de los hechos colectivos, las pautas de la psicología individual reconocida, la representación de la alta cultura, el conocimiento como la excepción redentora, la creación de atmósferas verbales como espejos de la comunidad. Y al cabo de las guerras de Reforma, en donde los conservadores se ven derrotados en lo militar, lo político y lo cultural, el breve lapso de la República Restaurada (1867-1876) es la primera culminación del hombre de letras, donde se fijan muchos de los rasgos de lo que será durante casi un siglo la vida literaria y periodística de México. El hombre de letras es poeta, cuentista, traductor, novelista, historiador, moralista y, con frecuencia, cronista. Al perder la crónica el tono urgente del compromiso de ideología y partido, se opta por lo que se llamará “costumbrismo", la tarea relatora que exhibe lealtades locales, regionales y nacionales, y el compromiso solidario: construir a esta sociedad que será una nación, fortalecerla desde la elección de vestuario para las fiestas, desde la predilección por un platillo, desde el sermoneo dedicado a las señoritas en edad de merecer.

No son precisas las fronteras entre cuento y crónica. Las tareas son semejantes: describir el pueblo, revelar caracteres y vitalidades ocultas o reprimidas, darle al habla las características de personaje máximo. Pero la semejanza no se agota en la aproxima- 
ción testimonial. También, a semejanza del cuento, la crónica explora los estilos literarios que son aficiones de sector y clase. El estilo coloquial de Guillermo Prieto contraviene las pretensiones neoclásicas de la "alta cultura", y en las crónicas liberales se filtran las formulaciones utópicas a manera de condenaciones del caos de la República.

Una ventaja frecuente de la crónica: el abandono de la rigidez que afecta a la producción "trascendente". Si el género es "pintoresco", carece de responsabilidades artísticas; ni es literatura de prestigio, ni es periodismo que estruje la conciencia. A partir de la República Restaurada la crónica se escribe para consignar impulsos y prevenciones de clase, la "intimidad" convertida en hecho público, la distribución del "sentir nacional" en hábitos, estructuras del diálogo y sistemas de relación. Y, last, but not least, con tal de cumplir deberes cívicos y morales, y complacer nostalgias.

En cuentos y novelas, los escritores cultos del siglo XIX optan por dar un carácter "típico" a los diálogos, y suelen ajustar el registro de las voces al único molde de la puerilidad, la búsqueda penosa del habla donde el pueblo se vuelve la eterna criatura. Sin ambiciones de eternidad, la crónica es más justa en su preservación de estilos y metamorfosis lingüísticas, usa con más humor los estereotipos, experimenta más. No hablo de ventaja alguna de la rapidez sobre el cultivo de la forma, sino de la manera en que la pretensión literaria de una etapa, sin obtener casi nada a cambio, ahogó algo básico: la espontaneidad, vital en una literatura emergente, el trato directo con zonas vitales del lenguaje. En cambio la crónica décimonónica, pese a la pudibundez sexual y al moralismo a que la obliga la censura, siempre mayor en diarios y revistas que en libros, capta sin el peso de la retórica lo que se vive y cómo se vive.

Ignacio Manuel Altamirano (1834-1893) se impone una tarea: crear una literatura nacional. No la empresa chovinista que el término hoy sugiere, sino la producción de poemas, cuentos, novelas, crónicas, ensayos, que tomen en cuenta de modo central y sin sensaciones de inferioridad las experiencias de la sociedad emergente (gustos, pasiones, ocios). Por la literatura México se regenerará, y hallará las vías del orgullo que es crecimiento psicológico y cultural. Para ejemplificar su credo, Altamirano incursiona en todos los géneros literarios, anima tertulias y veladas, patrocina escritores jóvenes, debate con los intolerantes. Y en sus numerosas crónicas se expresa su fe dual: en los atractivos de la vida estable, sin guerras, dedicada al comercio, la industria y las artes, 
y en las virtudes máximas de la tolerancia. La fe en la estabilidad lo lleva a la continua decepción, al anhelo impaciente de formas de vida metropolitanas. Frustrado por el ritmo lento y autocomplaciente de la periferia, Altamirano ya sólo cree a medias en lo que describe. A él lo indigna y deprime no encontrar en México los "robustos movimientos de la civilización". Atado por la rütina atroz, viaja "con la alforja vacía de novedades, de las calles de Plateros al paseo de Bucareli, de allí al Zócalo, del Zócalo a los desventurados teatros de la capital o a las imprentas que languidecen bajo el peso de una política soñolienta"'2. Le harta contemplar a los mismos pollos, beldades, jinetes, carruajes, malos cómicos, detestables piezas, cosas civiles y eclesiásticas. Su imaginación se enferma, nostálgica de lo desconocido, de lo nuevo, de lo diferente..., fastidiada ante la "vuelta de la noria" por las barrancas del paseo, las estacas de loros de Plateros y San Francisco, el agujero de grillos del teatro Principal, la cueva de búhos del Nacional, el avispero de Iturbide y las pastorelas del jardín de la Plaza Mayor, "sitio a propósito solamente para las églogas de los Nemorosos de almacén, y de las Filis de la aristocracia, que no es más que bourgeoisie traducida al francés"'.

Se queja Altamirano: la crónica en París, en Londres, en Berlín, en Nueva York, se alimenta a diario con novedades de importancia, porque son los grandes centros de la civilización del mundo. Pero en México, él se consume buscando asuntos amenos para sus revistas (crónicas), porque

México es una ciudad clorótica, pobre, mojigata, y a quien no conmueve de tiempo en tiempo sino el choque galvánico de las fiestas religiosas, o el estremecimiento débil todavía de las fiestas de la patria. México es una educanda de convento vestida con pretensiones a la francesa, pero conservando en su traje abigarrado y carnavalesco algunas piezas españolas y algunas aztecas. La enorme castaña de crepé, el puff y la pintura insolente, no alcanzan a disfrazar a la gazmoña mestiza, cuya sangre se ha debilitado entre las frías sombras del templo y de la celda, y cuyo espíritu se ha pervertido en el marasmo de una vida perezosa y en la barbarie de una educación de la Edad Media.

Altamirano describe con ironía y vigor el avance social y los ataques a la tolerancia apenas adquirida. Pero es José Tomás de Cuéllar (1830-1894), en la serie de crónicas noveladas La linterna

2 Ignacio Manuel Altamirano, Crónicas, t. 3, SEP, México, 1987, pp. 9 ss. 
mágica, publicada con el seudónimo de "Facundo", quien mejor da cuenta de los procesos internos de la sociedad que emerge. A Cuéllar le sucede lo que a la gran mayoría de los escritores: hereda algunas funciones del sacerdote, y se siente responsable del tono moral de la comunidad. Si Dios ya sólo se aloja en los templos, corresponde a los escritores distribuir los mensajes de reconvención. Cuéllar, como en algún nivel todos los cronistas de su tiempo, es un moralista que al narrar situaciones regala de paso moralejas robustas.

\section{JOSÉ TOMÁS DE CUÉLLAR: CREER EN LA IMPORTANCIA DEL VECINO PARA CONFIAR EN UNO MISMO}

Pero Cuéllar no es única ni principalmente moralista. Cada una de las novelas cortas o crónicas largas que integran La linterna mágica responde a un proyecto literario que trasciende con mucho el sermoneo. En Baile y cochino, Las jamonas, Ensalada de pollo o Los fuereños, lo que más importa es el deleite narrativo, la construcción de los personajes, el trazo de la sociedad como un gran chisme que se organiza en forma coral, el placer de la prosa, el don de síntesis. Así por ejemplo, en Baile y cochino, Enriqueta, una joven pobre que quiere dejar de serlo a como dé lugar, contempla desde su ventana el Paseo de la Reforma, y su avidez visual es una renuncia a los ideales de la honra:

Enriqueta estaba allí, como asomada al mundo, estacionada, como se estacionan esas pordioseras en el quicio de una puerta pidiendo una limosna. Pero la limosna que pedía Enriqueta, no era el pobre mendrugo cotidiano. Enriqueta pedía una limosna de lujo a la sociedad opulenta. Los ojos de Enriqueta se fijaban en la hilera de trenes de los ricos, y sus pupilas estaban agitadas por movimientos rapidísimos y pequeños, porque con cada mirada recorría el interior, el pescante y los frisones de un landó, o las siluetas de cuatro jóvenes en un faetón; caballos negros, colorados, retintos, con brillantes guarniciones; lacayos con librea, coches de familia, buggys, victorias y cupés; líneas de caballo y líneas de auriga; escorzos de mujer y dorsos de "gentlemen", portezuelas abiertas, fondos de carruaje acojinados, plumas de sombrero, beldades perdidas en la sombra, manos enguantadas, todo en movimiento, todo en perfiles fugaces, en líneas que apenas dejaban la impresión en la retina, eran borradas por otras y por otros en interminable vértigo ${ }^{3}$.

${ }^{3}$ JosÉ T. DE CUÉLLAR, La linterna mágica, sel. y pról. de M. Magdaleno, UNAM, México, 1941, p. 57. 
En cierto sentido, Cuéllar es el más moderno de los cronistas mexicanos del siglo XIX. A él le interesan en primer término las psicologías individuales, y no los arquetipos. Ya Fernández de Lizardi se fijó en los vínculos estrechísimos entre moda y discriminación social, pero es Cuéllar quien mejor se desenvuelve en los terrenos del candor, la ingenuidad, la credulidad, el humor involuntario. Para él, la crónica es el gran espejo en donde, al ser retratados, se aíslan, se magnifican, se vuelven francamente irrepetibles los defectos. Y la feria-de-vanidades habla de la indefensión del pueblo, que aún no genera los códigos morales de la vida laica.

\section{MANUEL GUTIÉRREZ NÁJERA:}

\section{LA GACERÍA DE SENSACIONES METROPOLITANAS}

Una de las funciones de la crónica decimonónica es el apuntalamiento de los presupuestos de la moral en su versión judeocristiana: defensa de la familia patriarcal, rechazo virulento de cualquier heterodoxia, protección de los seres indefensos por naturaleza, las mujeres. En novelas y cuentos tal estrategia de contención del pecado no escasea, pero donde se prodiga es en la crónica, el instrumento aleccionador de todos los días. En Manuel Gutiérrez Nájera (1859-1895), el cronista por excelencia de la sociedad porfiriana en su etapa de ascenso, la técnica se esmera. Él escribe guiado por las reverberaciones de la prosa, persuade a los lectores del brillo del lenguaje como metamorfosis de la banalidad, y, ya cumplida la tarea estilística, se da lujos: las pequeñas anécdotas de la comunidad pequeña, el sermoneo que es tributo social. Si la censura es severa, contribuyamos a ella para evadir algunos de sus rigores, y si no se puede hablar de política háblese de la "pequeña historia", donde florece la Sociedad Decente, que se observa a sí misma con mínimo humor y máximo detalle. (Quien se deleita relatando la lujuria en los escenarios, deberá acto seguido proteger la castidad y templanza de las señoritas).

Durante muchos años, a Gutiérrez Nájera lo preservaron del olvido una docena de poemas y una docena de cuentos. Luego, se ha visto de modo paulatino el conjunto de su acción de cronista, las miles de páginas escritas con su nombre o distintos seudónimos (El Duque Job, Perico el de los Palotes, Puck, Junius, M. Can Can, Recamier, El Cura de Jalatlaco, Ignotus, etcétera). Él cubre casi por su cuenta un periodo de la literatura mexicana que ve centrada en el espectáculo teatral y operístico, el centro de las conversaciones que es el eje de la vida cotidiana no tanto 
de un sector como de las pretensiones de una ciudad periférica, que elige a las divas operísticas y teatrales como símbolos de su afán de distanciarse del anonimato que la rodea, llamado gleba para ahorrar descripciones de su aspecto y su hedor.

Al criterio todavía determinante de la secularización (somos temerosos de Dios, pero ya somos igualmente temerosos del qué dirán y de nuestra opinión sobre nosotros mismos), Gutiérrez Nájera añade el examen minucioso del "brillo de la sociedad" que es seguridad de que el reino es de este mundo. De manera profusa describe los desprendimientos de la moral feudal, el crecimiento de los nuevos rituales ya no eclesiásticos, el gusto por vivir sin pensar obsesivamente en qué verdades seleccionar para el uso errátil del confesor. Gutiérrez Nájera, al tanto del escaso reconocimiento de la crónica, de la índole de su resonancia (en cuanto al impacto, la suelen aventajar el reportaje, el artículo político y, no tan ocasionalmente, la entrevista), experimenta con cuantía de sus registros. Escribe con enorme libertad, varía de tonos, usa de las diversas posibilidades del diálogo y, lo que más le divierte, no sólo juega a ser un "parisino avecindado en México", sino a inventar una sociedad entera de parisinos instantáneos. Casi por su cuenta, él lleva la creencia cultural del porfiriato (el "espíritu gálico" es la garantía de civilización) al detallismo, al seguimiento puntual de la moda, a la adopción de la mentalidad del voyeurista cultural, para quien lo parisino es lo cercano y lo mexicano lo exótico. El desarraigo es la empresa frívola que compensa a Gutiérrez Nájera por el trabajo exhaustivo, en las redacciones, y compensa a los lectores por recurrir a intermediarios. En razón de su sitio "'menor", la crónica, antes que hechos, deja traslucir convicciones profundas, profesiones de fe disfrazadas de lugares comunes, tradiciones verbales que desnudan modos de vida.

Un ejemplo del vivir-aquí-como-en-otra-parte. En 1880, Manuel Gutiérrez Nájera narra su visita a las tandas que nunca frecuentarían las gentes de origen social “adecuado". Él se siente "fuera de México": lo abruma el número de "fisonomías desconocidas" y lo alarma revisar los palcos en donde hay señoras, sin conocer a nadie. Algunas caras bonitas lo atraen: son "las perlas de esas conchas sucias que se llaman las casas de vecindad". Él, acostumbrado al reconocimiento en la calzada de la Reforma y en la calle de Plateros, está fuera de sitio:

El público ríe de todo estrepitosamente con carcajadas ordinarias de hombres que sólo asisten al teatro cuando se paga un real. El sombrero ancho extiende su enorme círculo junto a la chistera. 
La chaqueta codea con la levita. De todo aquel amasijo de carne humana, sube hasta la galería un acre olor confundido con el aroma del tabaco. Huele a gente ordinaria. A poco rato de estar soportando pacientemente aquel hedor, siente el estómago los primeros amagos de las náuseas. Comienzan las butacas y los palcos a bailar un cotillon informal ante los ojos. Cada risotada crispa los nervios espantosamente. La presencia de doña María pleiteando en las tablas aumenta el malestar, y es necesario retirarse, rompiendo, a fuerza de puños, esa barrera impenetrable que forman los espectadores a la entrada.

Una vez en la calle, libre ya de aquella atmósfera infestada de humo, el hombre sensato hace un solemne juramento: el de no pisar más aquel teatro.

Los oídos conservan todavía el repique de las últimas carcajadas. Su olfato está atrofiado por aquellos hedores imposibles. Necesita fumar durante una media hora y pasar dos veces por la droguería de Labadie, el más poderoso depósito de cloruro, para desinfectarse.

El marco de este relato escandalizado es la pretensión porfirista, que le exige a la "prensa decente" distanciarse a toda costa del vulgo. El público de Guillermo Prieto solía dividirse entre lectores y oyentes: quien sabía leer ejercitaba sonoramente su habilidad participándoles a vecinos y amigos de informaciones urgentes y de acontecimientos divertidos. Los lectores de Gutiérrez Nájera ya se sienten más seguros. Ellos son la Nación, porque descifran lo visible y lo oculto de la prensa y desconfían de antemano de las conclusiones sentimentales sobre la miseria. Ellos leen evitando confundir lo que ocurre en las calles con la realidad, y su actitud liquida un espejismo: el periodismo como sitio de encuentro entre las clases. Las mayorías se enteran por reflejo del pensamiento y los sucesos de las cúpulas, y las cúpulas aceptan la descripción del populacho sólo a nombre del pintoresquismo.

Gutiérrez Nájera, flâneur del fin del siglo mexicano. Pero, a diferencia del Baudelaire analizado por Walter Benjamin, Gutiérrez Nájera no pasea por la ciudad que se irá precisando y volviendo real, sino por la ciudad para siempre inexistente. Él inventa una sociedad para hacer caber en ella las vocaciones literarias. "Amó la forma, adoró la rima", e identificó a tal punto a Francia con el espíritu, que a través de la crónica de espectáculos propuso la utopía civilizada que le quedaba a mano: imaginarse París para alejar a un público de los orígenes que seguían siendo sus metas. 
MARTÍN LUIS GUZMÁN:

"FIERRO NO SE HABÍA MOVIDO DE SU SITIO"

Entre 1910 y 1920 no se advierte demasiado el peso de la Revolución en la producción cultural. Los escritores apoyan al dictador Huerta, huyen temiendo la venganza de los bárbaros, se refugian en el exilio interno, apoyan a una u otra facción revolucionaria, pero en las revistas no se transparentan las dimensiones de la guerra civil, ni se interrumpe el hábito de ver en la crónica la oportunidad por excelencia del gozo estilístico, de la prosa poética que finge ser informativa. La cumbre de tal preferencia es la crónica parisina que Rubén Darío inaugura, y continúan Amado Nervo, Enrique Gómez Carrillo, César Vallejo, Alejo Carpentier. París es todavía la capital del mundo, y enterarse de lo que allí ocurre -los espectáculos, las modas, los paseos, los personajes- es adquirir "sensaciones espirituales" a bajo costo. La crónica desde Europa, la técnica escapista que disfrutan en los cafés, las tertulias, las redacciones.

Lo común es alternar las crónicas parisinas con relatos de "color local". Ramón López Velarde, Rafael López, Amado Nervo, Luis G. Urbina, Luis González Obregón, Artemio de Valle-Arizpe exaltan la paz y la concordia y denuncian (de modo casi siempre implícito) la violencia que corroe los "barnices de civilización" y les revela otro país, ya no el de la pobreza aislable y pintoresquista, sino el de la miseria unánime y revanchista.

La Revolución afecta a la narrativa, pero no toca demasiado a la crónica, dependiente de diarios y revistas por lo común antirevolucionarios. Por eso sólo ocasionalmente se publican en libro las crónicas, y transcurren casi 15 años entre la publicación de México insurgente (1914) de John Reed y la de El águila y la serpiente (1928), ejemplos ambos de crónicas seguras, directas, no entorpecidas por el sentimentalismo. El águila y la serpiente narra la segunda educación sentimental de un joven escritor, lector de Platón y de Kant, en un medio donde rigen valores nuevos. Con maestría, Guzmán selecciona los hechos que propone como "esencia de la revolución'. (Así ocurrió, dice no tan entre líneas; la barbarie estalló y a los testigos nos corresponde el rechazo expreso y la admiración forzada). A Guzmán le obsesiona la perfección literaria por dos razones: es su obligación anímica, y es su distanciamiento seguro de la barbarie. Sólo un lenguaje clásico contendrá a la vez, sin distorsiones, el impulso de los caudillos y el de la grey astrosa. Sedimentado el 'caos, Guzmán se acerca a esa Revolución que fue en gran parte concurso de seres primitivos, y filtra 
una explicación: captar las acciones del primitivismo es asomarse a la esencia del pueblo que contradice a la Historia y la atrapa en círculos de fuego.

El punto culminante de El águila y la serpiente es el capítulo "La fiesta de las balas", donde adquiere aspectos de una épica invertida el asesinato de cerca de 300 prisioneros de guerra, que consuma una sola persona, Rodolfo Fierro, lugarteniente de.Villa. Según Guzmán, este acto monstruoso concentra la lógica vital de la plebe. El juicio es inapelable: el crimen es Fierro, Fierro y el villismo son "espejos contrapuestos, modos de ser que se reflejaban infinitamente uno en otro", y el villismo es la revolución popular y la revolución popular es el crimen. Luego, desde otra óptica, Guzmán escribirá Memorias de Pancho Villa, pero el juicio esencial se halla en "La fiesta de las balas", donde el crimen enmarca la única redención que Guzmán concibe: la belleza literaria. Concluido el relato de la matanza, Guzmán.prosigue:

Fierro no se había movido de su sitio. Rendido el brazo, lo tuvo largo tiempo suelto hacia el suelo. Luego notó que le dolía el índice y levantó la mano hasta los ojos: en la semiobscuridad comprobó que el dedo se le había hinchado ligeramente. Lo oprimió con blandura entre los dedos y la palma de la otra mano. Y así estuvo, durante buen espacio de tiempo, entregado todo él a la dulzura de un suave masaje. Por fin se inclinó para recoger del suelo el sarape, del cual se había desembarazado desde los preliminares de la ejecución; se lo echó sobre los hombros, y caminó para acogerse al socaire del pesebre. Sin embargo, a los pocos pasos se detuvo y dijo al asistente: - Así que acabes, tráete los caballos.

Y siguió andando .

Imposible saber si así fueron los hechos. Lo cierto es que ésa fue casi la única manera literaria de verlos. Sin la excelencia de Guzmán, en las abundantes crónicas sobre la Revolución (a veces disfrazadas de relatos) se repite el enfrentamiento entre civilización (el punto de vista del autor/lector) y barbarie (el hecho narrado). $\mathrm{Y}$-es el mensaje implícito- la noción depende del estremecimiento de horror de los lectores ante las masas ignaras y crueles. En el camino, una prosa de filos clásicos orienta el horror civilizado ante la Historia enredada en la barbarie. Tal estupefacción halla su síntesis inmejorable en el capítulo "Los zapatistas en Palacio'. Allí el líder campesino Eufemio Zapata, hermano de Emi-

4 “'La fiesta de las balas", en El águila y la serpiente, Porrúa, México, 1984, p. 209. 
liano, les enseña a los visitantes ilustres el Palacio Nacional, en manos del Ejército del Sur:

No subimos por la escalera monumental, sino por la de honor. Como portero que enseña una casa que se alquila, Eufemio iba por delante. Con su pantalón ajustado - de ancha ceja en las dos costuras exteriores-, con su blusa de dril - anudada sobre el vientrey con su enorme sombrero ancho, parecía simbolizar, conforme ascendía de escalón en escalón, los históricos días que estábamos viviendo, los simbolizaba por el contraste de su figura, no humilde, sino zafia, con el refinamiento y la cultura de que la escalera era como un anuncio. Un lacayo del palacio, un cochero, un empleado, un embajador, habrían subido por aquellos escalones sin desentonar: con la dignidad, grande o pequeña, inherente a su oficio y armónica dentro de la jerarquía de las demás dignidades. Eufemio subía como un caballerango que se cree de súbito presidente. Había en el modo como su zapato pisaba la alfombra una incompatibilidad entre alfombra y zapato; en la manera como su mano se apoyaba en la barandilla, una incompatibilidad entre barandilla y mano. Cada vez que movía el pie, el pie se sorprendía de no tropezar con las breñas; cada vez que alargaba la mano, la mano buscaba en balde la corteza del árbol o la arista de la piedra en bruto. Con sólo mirarlo a él se comprendía que faltaba allí todo lo que merecía estar a su alrededor, y que sobraba, para él, cuanto se veía en su entorno ${ }^{5}$.

\section{SALVADOR NOVO: LOS SUEÑOS DE LA ESTABILIDAD ENGENDRAN PAISAJES FRÍVOLOS}

La estabilidad relativa que el país, y sobre todo la capital, vive de manera creciente desde el gobierno de Álvaro Obregón requiere de gestores literarios (relatores, cantores). La exploración del universo rural y la temática de la Revolución Mexicana ocupan el espacio novelístico y hace falta una zona literaria consagrada sin mayores presiones extrañas a la vida sin sobresaltos, a la frivolidad que es negación de o ruptura con el ánimo trágico que al país le imponen la guerra y la miseria. No se trata de "huir de la realidad" a la usanza de los escritores colonialistas, sino de exhibir y de gozar los atractivos de la capital, entre ellos la disminución de hipocresías y la apetencia vanguardista de psicologías contradictorias, irónicas, desenfadadas. Es Salvador Novo (1904-1974) quien mejor representa en la crónica la voluntad de modernización ya presente en la poesía (López Velarde pese a todo, Pelli-

\footnotetext{
5 “Los zapatistas en Palacio", ibid., pp. 394-395.
} 
cer, los estridentistas), y apenas transmitida por la ficción. En $E l$ joven, un texto autobiográfico de los 18 años, Novo concluye:

Lo que hice hoy - dijo el joven soltando sus zapatos - no tendrá ya objeto mañana. Hay cosas invariables, que gustan siempre. Tengo sueño. Siempre me gustará dormir. Pero mañana se habrá muerto alguien. Hay estadísticas como leyes - no leyes mexicanasque se cumplen siempre. Yo puedo ser alguien y morirme. ¿Qué es un siglo para San Pedro? Sería divertido que yo resultara objeto de investigaciones. Se me acusa de ser muy alto. ¿Y por qué no habían de equivocarse los eruditos?

Y líneas antes ha dicho: "Siguió caminando. Todo lo conocía. Sólo que su ciudad le era un libro abierto por segunda vez, en el que reparaba hoy más, en el que no se había fijado mucho antes. Leía con avidez cuanto encontraba. ¡Su ciudad! Estrechábala contra su corazón. Sonreía a sus cúpulas y prestaba atención a todo"6.

¿Qué hay aquí de novedoso? La mezcla de un pensamiento a saltos, que procede por asociación paródica con el despliegue. de sentimientos consagrados. Tres años después, en 1925, Novo publica Ensayos, donde alternan poemas con textos influidos por la tradición inglesa de The Spectator y Charles Lamb, que descree de la importancia absoluta de los temas. La prosa redime o descubre la fuerza de lo considerado "insignificante", y da pleno sentido al hecho de ocuparse de los anteojos, el baño, las camas, el radio, las barbas, la leche, el divorcio, las ventajas de no estar a la moda. Ya los modernistas implantaron en el periodismo esta creencia (la prosa lo es o lo justifica todo), pero, a diferencia de ellos, Novo no se propone textos programadamente literarios, joyas prosódicas cuya exacta dimensión sólo proviene de lecturas en voz alta; él le da al artículo o al pequeño ensayo un ritmo distinto, ya no derivado del lenguaje poético "profesional" ni de las aspiraciones del "logro acústico", el ritmo de un pensamiento moderno que combina información, erudición, inteligencia, experimentación prosística, cultura clásica, vida cotidiana, actualidad tecnológica, Siglo de Oro y The New Yorker, Wilde y el gossip de la vida citadina, Quevedo y la nueva poesía anglosajona. El elemento unificador es la ironía, la distancia intelectual y anímica entre el tema y el escritor, que solicita la correspondiente mala fe del lector. vamente.

${ }^{6}$ Cito por la edición de Mundial, México, 1933, pp. 56 y 14 respecti- 
El resultado es sorprendente. Novo asimila con rapidez las influencias, y los lectores agradecen la originalidad de los puntos de vista que se traducirán en fraseos sardónicos y motivos de conversación. En un medio regido por la obsesión de "construir un país nuevo", alguien elige con insolencia las posiciones de la "frivolidad" y prefigura ocios y complacencias de la sociedad inminente. Es un testigo profético.

"Ya en 1922 - acepta Novo en 1929 - estaba yo maduro para empleos. Podría dar clases, podría hacer traducciones'. Él de nada se priva, y en "este cotejo del valor propio con el éxito ajeno que engendra místicos" opta por el periodismo. Allí alterna ensayos breves y artículos en defensa de "lo usado" y lo cotidiano, con la columna política y las crónicas que imponen con beligerancia la subjetividad sin culpa del escritor en la sociedad burguesa. Gracias al periodismo, Novo se instaura triunfalmente como literatura y como personaje. Él explica su éxito con la lucidez que le allega una modestísima vanidad:

La gimnasia que entraña escribir a tantos rounds con límite de tiempo en los periódicos, mientras aspira a convertir a quien la practica en un atleta, puede también con facilidad conducir a la acrobacia. Mi estilo se hizo claro y ágil; pero diferí, engreído en el columpio, el acometer la empresa más ardua de una obra menos efímera. Si ello era malo para mí, resultó en cambio bueno para las revistas y periódicos en que colaboraba. Mi ejemplo fue seguido y el nivel de las columnas se elevó considerablemente. No desconozco el hecho de que antes de mí, y después, los escritores hayan compartido la elaboración lenta, oculta y heroica de su verdadera obra, con el periodismo: la maternidad clandestina con la prostitución pública. Simplemente confieso, relativamente arrepentido, que a mí me arrastró la prostitución, circunstancia de la que me consuela la esperanza de haberla un poco ennoblecido.

André Gide, quizás la influencia moral por excelencia del grupo de Contemporáneos, emite el dictamen: "No hay que exponer nunca ideas, a no ser bajo la forma de temperamentos y caracteres''. En crónicas y ensayos, Novo elige un temperamento, el suyo propio, y una suma de caracteres: los relativos a la ciudad de México. Para él, en su abundante producción periodística, la capital es un placer minucioso: el de intimar, discreción mediante, con la burguesía en ascenso. Los caracteres circundan y devoran el temperamento, pero no sin que éste se asegure honores y admiración genuina, y no sin que la provocación - como suele suceder - se convierta en institución.

Lo novedoso: que a los lectores les interese, les divierta, los 
retenga el vagabundeo mental de un escritor que desatiende las exhortaciones de la Historia y actúa al margen de las Sensaciones Cívicas. Novo, básicamente sedentario, retorna en cuatro libros a un gran género del siglo XIX: la crónica de viajes. En Return Ticket (1928), Jalisco, Michoacán (1933), Continente vacio (1935) y Este $y$ otros viajes (1951), Novo transfiere sus dotes narrativas a la crónica, se entusiasma ante seres y situaciones juzgados "intrascendentes", y crea un personaje muy convincente (él mismo) usando sólo anotaciones externas: su éxito social, su ingenio perdurable, su gusto por la buena mesa, su memoria que es la de un observador atento y ubicuo, de cuyo registro nadie escapa y cuya curiosidad es infatigable. Su reto literario es muy preciso: convertir en hecho memorable lo banal, un viaje a Querétaro, las giras oficiales.

Una sección, de entre las muchas que Novo produce, es vehículo óptimo de su talento: "La semana pasada" en el semanario Hoy de los años treinta. Allí Novo, auxiliado por un equipo de jóvenes reporteros, pone al día un género admonitorio y propagandístico: el artículo político. Influido por las crónicas parisinas de Janet Flanner (Genet) en The New Yorker, y determinado por su percepción de la política como la picaresca inadvertida, Novo equilibra su capacidad de síntesis con el pesimismo irónico propio de un conservador inteligente. En la recopilación de "La semana pasada", La vida en México en el periodo presidencial de Lázaro Cárdenas, un estilo (un punto de vista al que sólo se hace justicia citándolo textualmente) alcanza su absoluta brillantez. Los resúmenes biográficos, las descripciones de la administración cardenista, las incursiones en la política mundial, el examen de las resonancias cotidianas de la política, son todavía puntos de referencia, pese a posiciones reaccionarias y actitudes xenófobas.

$\mathrm{Al}$ concluir el gobierno de Cárdenas, Novo se entrega a una crónica muy personal (o muy colectiva, como se prefiera) que, primero en Hoy y luego en Mañana, elige para verterse el recurso del "Diario" o las "Cartas a un amigo". Cada vez más satisfecho de su progreso, y más convencido de los beneficios de la respetabilidad y la comodidad burguesa, Novo se decide por una falsa y verdadera confesión intimista. Tiene un público a su disposición: el que acepta la trayectoria y el tedio de una capa dirigente como sus propios progreso y alborozo. Otras recopilaciones disponibles (Toda la prosa, La vida en México en el periodo presidencial de Manuel Ávila Camacho, La vida en México en el periodo presidencial de Miguel Alemán, Las locas, el sexo y los burdeles) ensalzan el modo de vida de la ciudad pretensiosa. Y sin embargo, la honestidad literaria de Novo, su deseo de difundir el goce de la intimidad con 
los círculos dirigentes, confieren a sus crónicas la doble seducción de verificar el tránsito de un personaje y las limitaciones de una élite.

En 1948, Novo gana un concurso del Departamento Central con un libro fundamental en su bibliografia: Nueva Grandeza Mexicana, donde el personaje mitificable se instala en el centro de la crónica mitificadora, y se cubren con entusiasmo las distancias entre el Yo y la Ciudad, entre las magnas ambiciones y los escenarios pequeños. Al desarrollismo estatal, Novo le ofrece el recorrido por una capital que es una sociedad entreabierta, por una geografía de la imaginación pluriclasista que es una velada inolvidable, por una zona de anécdotas, amistades y conocimientos privilegiados que es, para los lectores de entonces, el único mundo disponible. La tradición es un conocimiento hogareño y nada hay en la ciudad amenazador, hostil o en verdad desconocido. La Unidad Nacional que pregonan los gobiernos es también confianza en el expansionismo urbano sin consecuencias. Este México donde cada quien ocupa un lugar fijo, es, sin duda, una trampa ideológica que le da apariencia de bonhomía a un capitalismo feroz, el territorio de concordia idealizada que la estabilidad regala.

Hoy, las crónicas de Novo resultan indispensables, no tanto para conocer una época (su parcialidad lo impide), sino para observar cómo se introduce la prosa moderna desde el periodismo, con un objetivo declarado: narrar las sensaciones de bienestar y autocomplacencia, propias de la élite que se refina y se internacionaliza. Ya no procede, por lo demás, el antiguo desafío. El elitismo de los veintes, dinámico y estimulante, se torna el atrasado y pomposo elitismo que corona y ornamenta a sociedad y Estado. A los palurdos que se burlaban de los exquisitos los sustituyen políticos y técnicos fascinados con los roces y los acompañamientos de la cultura, ya indispensable telón de fondo. Los happy few de la década del veinte se multiplican y, al hacerlo, se diluyen y hacen rentable su felicidad minoritaria. Ya sin presiones, Novo se consagra, entre crónicas desarmadas, ingenio jamás industrializado y erudición sabrosamente dicha, al manejo escénico de quienes en un tiempo lo proscribieron por sus preferencias sexuales. Él, despiadada e injustamente, describe su proceso:

Llevo una especie de veinte años de escribir para el público. Primero, era el poeta joven que prometía mucho. Luego, seguía prometiendo. Después, se descubrió mi capacidad, tanto de trabajo cuanto de mordacidad, y poco a poco, fui comercializando mis aptitudes, como un pulpo que extiende sus tentáculos. El colmo fue vaciar en una columna cotidiana hasta los cracks que corrientemente me 
ocurren en la conversación. Era como cobrar hasta por reírme, si no hubiera acabado por ser hasta reírme por cobrar?

ELENA PONIATOWSKA: EL REGISTRO DE LA NUEVA ÉPICA

¿Quién hace periodismo pudiendo escribir cuentos y novelas? El auge de la narrativa provoca, una vez más, en el medio cultural, la arremetida contra el periodismo, "enemigo de la promesa". Ante el prestigio de la ficción, la crónica se extravía en la nostalgia profesional, y la despolitización y la censura vetan el acercamiento a huelgas, rebeldías y modos de vida populares vistos sin condescendencia. Y es muy difícil trasladar a la crónica así entendida los ritmos de la gran ciudad, cuyo cambio vertiginoso cancela opciones narrativas, tratamientos lineales, antiguas emociones.

Novo hizo del registro de su estado de ánimo el índice del avance social, y de la descripción de su tedio un catálogo implícito de anacronismo ("lo que me aburre no es moderno"). En el polo opuesto, Fernando Benítez, en su serie sobre los indios de México, muestra la coherencia interna y la riqueza cultural de un mundo cerrado por el racismo y la explotación. Y será Elena Poniatowska (nacida en 1933) quien pruebe con su obra la disolución de los géneros, la mezcla de lo único y lo multitudinario, los modos en que la ficción se aprovecha del reportaje y la novela se contamina de procedimientos periodísticos. Al principio Poniatowska opta por la viveza costumbrista, y en 1963 las viñetas capitalinas compiladas en Todo empezó en domingo son homenaje a lo que no termina de extinguirse, paseo "a la antigua" por paisajes aún tradicionales. Luego, en 1969, en Hasta no verte Jesús mío, la vida-novela de Jesusa Palancares, mujer del pueblo, Poniatowska ya rechaza cualquier pintoresquismo.

Oscar Lewis fue a las vecindades y desprendió de lo allí observado y grabado un enorme prejuicio teórico: "la cultura de la pobreza", la idea de que los pobres convierten siempre sus experiencias en ideología del fatalismo. Desde técnicas semejantes, Poniatowska llega a conclusiones opuestas y convierte la vida de Jesusa Palancares en relato de múltiples niveles, sin moralejas sociológicas, sin tremendismos que obliguen al lector a concentrarse no en lo leído sino en la respuesta moral que se le demanda. Crónica del costo interminable de la marginación social, autobiografía de clase y de sexo, finísimo registro de las variaciones del habla a través de la vida de una persona, creación de una figura

${ }^{7}$ Hoy, México, septiembre de 1943. 
protagónica que es mucho más que la suma de episodios vitales, Hasta no verte Jesús mío niega los procedimientos naturalistas o "neorrealistas" que eran métodos probados de inmersión en terrenos de la pobreza, e inicia el tratamiento literario de las mujeres sin privilegios.

Los sucesos de 1968 revitalizan y diversifican la crónica. La noche de Tlatelolco, el libro ya clásico de Poniatowska, es crónica coral, reportaje fragmentario, montaje de voces que corresponden a tomas de conciencia y hechos represivos. Gracias al hábil entramado de imágenes narrativas y testimonios, Poniatowska reconstruye las dimensiones subjetivas del movimiento estudiantil, la espontaneidad que se compensa con arrojo, la ideología visceral y la épica a la vuelta de la esquina. La noche de Tlatelolco muestra por inferencia a la densa capa mortuoria de la vida política de México, la sensación de un país bajo una campana neumática. En este collage, Poniatowska preserva en forma memorable el poderío humano y político del 68.

En Fuerte es el silencio (1975), Poniatowska mezcla todas las tradiciones de la crónica: la evocación sentimental, el recuento político, el relato mítico, la novela corta sin ficción, la viñeta, la estampa, el ensayo. Y en buena medida la actitud de Poniatowska depende de la pérdida del temor al uso "heterodoxo" de los géneros.

Otras obras de gran importancia: las de Ricardo Garibay (en especial su tratamiento de mundos marginales: Acapulco, Las glorias del gran Púas), Vicente Leñero (en especial, Asesinato, la reconstrucción de los asesinatos del ex-político Gilberto Flores Muñoz y su esposa), las reconstrucciones históricas de Luis González y las históricas y literarias de José Emilio Pacheco. Y junto a esto, la producción de nuevos autores que ni magnifican ni minimizan la crónica, otro espacio literario aprovechable. Desvanecido el sentimiento de embriaguez histórica que hizo posible Memorias de mis tiempos o El águila y la serpiente, queda la voluntad de registrarlo todo para que el tiempo y los lectores discriminen. Democratizada la noción de Historia, la crónica la multiplica en su variedad de aproximaciones literarias a manifestaciones, almacenes de Suburbia, modas de los mass-media, excéntricos que no lo son tanto, vivencias de alta y baja política, vida cotidiana en las márgenes. Mudo espío, mientras alguien voraz a mí me lee.

CARLOS MONSIVÁIS

México, D.F. 